\title{
Peningkatan Prestasi Belajar Materi Rasul-rasul Allah melalui Model Talking Stick pada Siswa Kelas V SD
}

\author{
Sugito $^{(1)}$ \\ ${ }^{1}$ SDN 3 Gembleb Kecamatan Pogalan Trenggalek \\ Email: ${ }^{1}$ 7363@gmail.com, \\ DOI: https://doi.org/10.28926/riset_konseptual.v2i3.63
}

\begin{abstract}
ABSTRAK
Rendahnya prestasi belajar Pendidikan Agama Islam siswa SDN 3 Gembleb Kecamatan Pogalan Kabupaten Trenggalek dan Guru enggan melaksanakan model pembelajaran inovatif penelitian tindakan kelas dilakukan. Tujuan Penelitia Tindakan Kelas (PTK) untuk mendapatkan gambaran objektif peningkatan prestasi belajar Pendidikan Agama Islam melalui model pembelajaran Talking Stick Siswa Kelas V SDN 3 Gembleb Kecamatan Pogalan Kabupaten Trenggalek. Subjek adalah siswa kelas V SDN 3 Gembleb Kecamatan Pogalan Kabupaten Trenggalek semester 2 tahun pelajaran 2017/2018. Jumlah 11 siswa, terdiri 7 siswa laki-laki dan 4 siswa perempuan. Hasil siklus I Siswa tuntas 8 siswa (73\%), pada siklus II sejumlah 11 siswa $(100 \%)$, terjadi kenaikan sebesar $27 \%$ atau sebanyak 3 siswa dari 11 siswa. Nilai ratarata kelasn pada siklus I sebesar 73 dan siklus II mencapai 85, terjadi kenaikan 17 poin. Berdasarkan hasil Penelitian Tindakan Kelas, maka terjadi peningkatan prestasi belajar Pendidikan Agama Islam materi Rasul-Rasul Allah melalui model pembelajaran Talking Stick pada siswa kelas V di SDN 3 Gembleb Kecamatan Pogalan Kabupaten Trenggalek Semester II Tahun Pelajaran 2017/2018.
\end{abstract}

Kata kunci: talking stick, rasul-rasul allah,

\section{PENDAHULUAN}

Belajar berhubungan dengan perubahan tingkah laku seseorang terhadap suatu situasi tertentu yang disebabkan oleh pengalamannya yang berulang-ulang dalam situasi itu, dimana perubahan tingkah laku itu tidak dapat dijelaskan atas dasar kecenderungan respon pembawaan, kematangan atau keadaan-keadaan sesaat seseorang (misalnya kelelahan, pengaruh obat, dan sebagainya. Perubahan yang merupakan hasil belajar adalah perubahan yang sifatnya relative mantap. Artinya, perubahan tersebut bersifat tahan lama dan tidak mudah hilang. Oleh karena itu perubahan yang hanya bersifat sekejap bukanlah hasil belajar, misalnya perubahan pada saat mengalami gangguan kesehatan, bukanlah merupakan hasil belajar. Karena perubahan tersebut tidak diperoleh dari hasil latihan, dan akan hilang apabila rasa sakitnya sudah hilang.

Pengertian prestasi dikatakan hasil dari suatu kegiatan yang telah dikerjakan, diciptakan, baik secara individual maupun kelompok (Djamarah, 2011:19). Selanjutnya prestasi belajar merupakan penguasaan pengetahuan atau ketrampilan yang dikembangkan oleh mata pelajaran, lazimnya ditunjukkan dengan nilai test atau angka nilai yang diberikan oleh guru (Depdikbud, 2010:700). Prestasi belajar merupakan hasil yang dapat dicapai siswa setelah siswa melakukan kegiatan belajar. Whittaker dalam Wasty Soemanto menyatakan bahwa: "Belajar dapat didefinisikan sebagai proses dimana tingkah laku dalam arti luas ditimbulkan atau diubah melalui latihan atau pengalaman" (Soemanto, 1983:99). Pengertian belajar mengandung arti bahwa belajar adalah adanya perubahan perilaku. Siswa yang melakukan kegiatan belajar tentunya akan menunjukkan perubahan dalam dirinya. Misalnya siswa yang belajar Matematika juga akan mengalami perubahan pengetahuan di bidang Matematika, dan sebagainya.

Surya menyatakan bahwa ciri-ciri belajar adalah (1) perubahan yang disadari dan disengaja. Artinya perubahan dalam kegiatan belajar adalah perubahan yang 
Vol. 2 No. 3, Juli 2018;

sifatnya disadari dan disengaja. Hal tersebut dikarenakan belajar adalah kegiatan yang disadari dan disengaja pula. Belajar adalah kegiatan yang mempunyai tujuan yang ingin dicapai oleh individu yang belajar. (Kosasih, 2015:4), (2) perubahan yang berkesinambungan. Artinya perubahan yang terjadi selalu berkaitan antara kemampuan yang sebelumnya dan sesudahnya. Siswa akan belajar mulai dari hal yang mudah menuju ke yang lebih sulit. Jadi pengalaman siswa yang sebelumnya akan berkaitan dengan belajar yang berikutnya. Misalnya sebelum siswa belajar membuat kalimat, terlebih dulu diajari mencoret, menulis huruf, menulis kata, baru menulis kalimat, dan begitu seterusya (Kosasih, 2015:4), (3) perubahan yang fungsional. Artinya perubahan sebagai hasil belajar adalah perubahan yang sifatnya fungsional, yakni dapat dimanfaatkan oleh individu yang belajar (Kosasih, 2015:5), (4) perubahan yang bersifat positif. Artinya perubahan yang dapat digolongkan sebagai hasil belajar adalah perubahan yang sifatnya positif. Misalnya setelah mempelajari berbagai macam hewan, maka tumbuh rasa syukur pada diri siswa terhadap Tuhan yang telah menciptakan hewan yang mempunyai banyak manfaat bagi manusia (Kosasih, 2015:5), (5) perubahan yang bersifat aktif. Artinya perubahan sebagai hasil belajar adalah perubahan yang bersifat aktif, bahwa untuk mendapatkan perubahan yang diinginkan, siswa harus aktif dalam melibatkan pikiran dan fisiknya dalam kegiatan pembelajaran (Kosasih, 2015:5), (6) perubahan yang bersifat relative permanen. Artinya perubahan sebagai hasil belajar bersifat relative permanen, tidak mudah hilang. Perubahan yang mudah hilang bukanlah hasil belajar, tetapi hanya merupakan perubahan sesaat. Misalnya ada anak yang ketakutan karena didekati anjing maka ketakutan tersebut akan hilang jika anjingnya menjauh, (7) perubahan yang bertujuan. Artinya seseorang biasanya belajar karena ingin menguasai sesuatu. Misalnya seseorang kuliah di kedokteran karena dia ingin menguasai ilmu kesehatan, dan sebagainya (Kosasih, 2015:5), dan (8) perubahan perilaku secara keseluruhan. Artinya perubahan sebagai hasil belajar adalah perubahan secara keseluruhan, dimana meliputi berbagai aspek, baik sikap, pengetahuan, ataupun ketrampilan, baik yang bersifat jasmani maupun rohani (Kosasih, 2015:5).

Gagne dalam Kosasih menyatakan bahwa perubahan perilaku yang dimaksud mencakup 5 hal, yakni informasi verbal, yaitu penguasaan informasi dalam bentuk bahasa, kecakapan intelektual, yaitu ketrampilan seseorang dalam melakukan interaksi dengan lingkungannya dengan menggunakan simbol-simbol, strategi kognitif, yakni kecakapan seseorang untuk melakukan pengedalian dan pengelolaan keseluruhan aktifitasnya. Dalam konteks proses pembelajaran, strategi kognitif yaitu kemampuan mengendalikan ingatan dan cara-cara berfikir agar terjadi aktifitas yang efektif, sikap, yaitu hasil pembelajaran yang berupa kecakapan seeorang untuk memilih tindakan yang akan dilakukan, dan kecakapan motorik, yaitu hasil belajar yang berupa kecakapan pergerakan yang dikontrol oleh fisik. (Kosasih, 2015:5).

Mohammad Surya dalam Kosasih menyatakan bahwa hasil belajar akan tampak pada (1) kebiasaan, misalnya seseorang yang belajar bahasa akan berusaha menghindari pemakaian struktur yang salah, maka dia akan terbiasa menggunakan bahasa yang baik dan benar, (2) ketrampilan, misalnya menulis dan berolah raga yang memerlukan koordinasi gerak motoric, (3) pengamatan, yakni proses menerima, menafsirkan dan memberi arti rangsangan yang masuk, (4) merfikir asosiatif, yakni berfikir dengan cara mengasosiasikan sesuatu dengan lainya dengan menggunakan daya ingat, (5) berfikir rasional dan kritis, yakni menggunakan prinsip-prinsip dan dasar-dasar pengertian dalam menjawab pertanyaan kritis seperti bagaimana dan mengapa, (6) sikap, yakni kecenderungan yang relatif menetap untuk bereaksi dengan cara baik atau buruk terhadap orang atau barang tertentu sesuai dengan pengetahuan dan keyakinan, (7) inhibisi, yaitu kemampuan untuk menghindari hal yang tidak perlu dari suatu tindakan, (8) apresiasi, yaitu kemampuan untuk menghargai suatu karya, bentuknya berupa pujian atau jenis penghargaan lainnya, dan perilaku afektif, yaitu perilku yang berkaitan dengan perasaan takut, marah, sedih, gembira,kecewa, dan sebagainya. (Kosasih, 2015:5). 
Vol. 2 No. 3, Juli 2018;

Model pembelajaran Talking Stick berkembang dari penelitian belajar kooperatif oleh Slavin Pada tahun 1995. Model ini merupakan suatu cara yang efektif untuk melaksanakan pembelajaran yang mampu mengaktifkan siswa. Dalam model pembelajaran ini siswa dituntut mandiri sehingga tidak bergantung pada siswa yang lainnya. Sehingga siswa harus mampu bertanggung jawab terhadap diri sendiri dan siswa juga harus percaya diri dan yakin dalam menyelesaikan masalah. Model pembelajaran Talking Stik adalah suatu model pembelajaran kelompok dengan bantuan tongkat, kelompok yang memegang tongkat terlebih dahulu wajib menjawab pertanyaan dari guru setelah siswa mempelajari materi pokoknya, selanjutnya kegiatan tersebut diulang terus-menerus sampai semua kelompok mendapat giliran untuk menjawab pertanyaan dari guru. Pembelajaran talking stick merupakan salah satu dari model pembelajaran kooperatif yang menggunakan sebuah tongkat sebagai alat penunjuk giliran dengan memberikan siswa kesempatan untuk bekerja sendiri serta bekerja sama dengan orang lain sehingga mengoptimalisasikan partisipasi siswa. (Fathurrohman, 2010: 63-65). Penerapan metode pembelajaran Talking Stick dapat menimbulkan rasa senang pada diri siswa karena metode Talking Stick bersifat permainan yang menyenangkan. Permainan Talking Stick dikatakan menyenangkan karena didalam tongkat tersebut tidak hanya berisi soal-soal tetapi juga soal kosong atau soal pengalihan untuk menghindari terjadinya senam jantung pada diri siswa dan karena permainan tersebut diiringi oleh iringan musik.

Sintaks atau langkah-langkah pembelajaran dengan menggunakan model pembelajaran talking stick, yaitu guru menjelaskan tujuan pembelajaran/KD, guru menyiapkan sebuah tongkat, guru menyampaikan materi pokok yang akan dipelajari, kemudian memberikan kesempatan kepada siswa untuk membaca dan mempelajari materi lebih lanjut, setelah siswa selesai membaca materi/buku pelajaran dan mempelajarinya, siswa menutup bukunya dan mepersiapkan diri menjawab pertanyaan guru, guru mengambil tongkat dan memberikan kepada siswa, setelah itu guru memberikan pertanyaan dan siswa yang memegang tongkat tersebut harus menjawabnya, jika siswa sudah dapat menjawabnya maka tongkat diserahkan kepada siswa lain. Demikian seterusnya sampai sebagian besar siswa mendapat bagian untuk menjawab setiap pertanyaan dari guru, dan guru memberikan kesimpulan (Fathurrohman, 2010:65).

Kelebihan dari model pembelajaran Talking Stick adalah siswa terlibat langsung dalam kegiatan belajar, terdapat interaksi antara guru dan siswa, siswa menjadi lebih mandiri, dan kegiatan belajar lebih menyenangkan. Adapun kekurangan dari model pembelajaran Talking Stick adalah siswa cenderung individu, materi yang diserap kurang, siswa yang pandai lebih mudah menerima materi sedangkan siswa yang kurang pandai kesulitan menerima materi, guru kesulitan melakukan pengawasan, ketenangan kelas kurang terjaga (Fathurrohman, 2010:65).

\section{METODE}

Penelitian dirancang dalam penelitian tindakan kelas menerapkan model pembelajaran Talking Stick untuk meningkatkan profesionalitas guru sebagai agen dan fasilitator pembelajaran melalui perubahan pelaksanaan proses belajar mengajar menjadi proses pembelajaran yang inovatif. Penelitian Tindakan Kelas bersifat reflektif melakukan tindakan-tindakan tertentu untuk memperbaiki atau meningkatkan praktek pembelajaran di kelas secara proposional diarahkan meningkatkan prestasi belajar Pendidikan Agama Islam. Penelitian tindakan kelas ini dilaksanakan dalam empat tahap, yaitu (1) tahap perencanaan (2) tahap pelaksanaan (3) tahap pengamatan, dan (4) tahap refleksi.

\section{Rancangan Penelitian}

Penelitian Model Kemmis dan Taggart (Arikunto, 2015:73) ini merupakan jenis penelitian tindakan kelas atau biasa disingkat PTK, pertama kali diungkapkan oleh Kurt Lewin pada tahun 1944. Bermakna bentuk penelitian yang bersifat reflektif dengan 
Vol. 2 No. 3, Juli 2018;

melakukan tindakan-tindakan tertentu untuk memperbaiki dan meningkatkan praktek pembelajaran di kelas secara lebih berkualitas sehingga siswa dapat memperoleh hasil belajar yang lebih baik (Asrori, 2011:6).

\section{Perencanaan}

Tahap yang dilakukan dalam penelitian ini adalah pembelajaran dengan menggunakan model pembelajaran Talking Stick. Pada tahap perencanaan dilaksanakan kegiatan sebagai berikut Guru menyiapkan RPP, Guru menyusun LKS, Guru menentukan sumber belajar yang dipergunakan, Guru menentukan media yang dipergunakan, Guru menyusun lembar pengamatan, Guru menyusun soal tes akhir, dan Menyiapkan daftar hadir

\section{Pelaksanaan Tindakan}

Pelaksanaan tindakan melaksanakan tindakan sesuai dengan RPP yang telah disiapkan. Pelaksanaan tindakan relevan dengan model pembelajaran yang diterapkan yakni model Talking Stick. Langkah-langkah pembelajaranya adalah sebagai berikut Persiapan, Pembentukan kelompok, Persiapan buku sumber, Diskusi masalah, Memanggil nomor anggota, Memberi kesimpulan, dan Guru megadakan tes akhir bagi siswa (Fathurrohman, 2015:82).

\section{Pengamatan}

Pengamatan dilakukan oleh guru Selama proses pembelajaran berlangsung. Hasil pengamatan dimasukkan dalam format pengamatan. Aspek yang dinilai adalah keaktifan siswa pada saat pembelajaran berlangsung. Adapun fokus pengamatan terletak pada kegiatan inti pembelajaran yang menggunakan model pembelajaran talking stick.

\section{Refleksi}

Pada tahap ini merefleksi pembelajaran yang telah berlangsung untuk mengetahui kelebihan dan kekurangan yang terjadi pada saat pembelajaran. Hal-hal yang dilakukan pada tahap ini adalah menganalisis hasil pengamatan dalam pembelajaran tentang keaktifan siswa, menganalisis hasil kerja siswa yang diperoleh dari tes akhir setiap siklus, mengevaluasi kegiatan pembelajaran yang telah berlangsung dan mencari alternatif pemecahan dari kekurangan yang muncul. Penelitian tindakan kelas ini direncanakan akan berlangsung selama 3 bulan, dan masing-masing siklus akan dilalui melalui 4 tahapan, yakni : perencanaan, tindakan, pengamatan, dan refleksi.

\section{Teknik Pengumpulan Data}

Teknik pengumpulan dalam penelitian tindakan kelas ini berupa hasil pengamatan melalui observasi untuk memperoleh data aktivitas belajar siswa selama mengikuti proses pembelajaran. Teknik pengumpulan data yang dipergunakan pada penelitian ini adalah teknik test dan non tes. Teknik tes dilakukan untuk memperoleh nilai akhir siswa. Sedangkan teknik non tes dilakukan untuk memperoleh prosentase keaktifan siswa.

\section{Teknik Analisis Data}

Penelitian menggunakan teknik analisis deskriptif kualitatif, yaitu suatu metode penelitian yang bersifat menggambarkan kenyataan atau fakta sesuai dengan data yang diperoleh dengan tujuan untuk mengetahui prestasi belajar yang dicapai siswa juga untuk memperoleh respon siswa terhadap kegiatan pembelajaran serta aktivitas siswa selama proses pembelajaran setiap siklus dilakukan dengan cara memberikan evaluasi. Analisis ini dihitung dengan menggunakan statistik sederhana yaitu (1) data tentang prestasi belajar siswa. Data ini dianalisis dengan cara (a) membuat tabel kualifikasi nilai, (b) mencari nilai rata-rata kelas, (c) mencari prosentase ketuntasan, (c) 
Vol. 2 No. 3, Juli 2018;

menentukan modus, dan (d) menentukan peningkatan prestasi belajar, dengan cara mencari selisih antara hasil dari Siklus I dengan hasil pada siklus II.

\section{HASIL}

Hasil prasiklus diketahui Peneliti melakukan tindakan sesuai dengan metode yang diterapkan, yakni metode ceramah. Hasil test akhir yang diperoleh siswa tuntas pada tahap pra siklus mencapai 7 siswa (64\%). Selebihnya yakni sebanyak 4 siswa $(36 \%)$ belum tuntas. Analisis berdasarkan kategori dapat disampaikan siswa dalam kategori istimewa sebanyak 0 siswa $(0 \%)$. Siswa dalam kategori sangat baik sebanyak 1 siswa (9\%), siswa dalam kategori baik sebanyak 1 siswa (9\%), dan siswa dalam kategori cukup sebanyak 5 siswa (46\%). Sedangkan sebanyak 4 siswa (36\%) siswa yang lain dalam kategori kurang. Modus muncul pada nilai 70, sebanyak 5 siswa (45\%). Nilai rata-rata kelas adalah 72 . Refleksi yang dilaksanakan pada pra siklus menghasilkan beberapa masukan, yakni Guru kurang memotivasi siswa dalam kegiatan belajar, dan pada saat mengajar guru masih disibukkan dengan tugas yang lain.

Hasil siklus I dilaksanakan dengan model pembelajaran Talking Stick, diketahui bahwa siswa tuntas pada tahap siklus I mencapai 8 siswa (73\%). Selebihnya yakni sebanyak 3 siswa (27\%) belum tuntas. Analisis berdasarkan kategori dapat disampaikan sebagai berikut siswa dalam kategori istimewa sebanyak 0 siswa (0\%). Siswa dalam kategori sangat baik sebanyak 1 siswa (9\%), siswa dalam kategori baik sebanyak 4 siswa (36\%), dan siswa dalam kategori cukup sebanyak 3 siswa (27\%). Sedangkan sebanyak 3 siswa (27\%) siswa dalam kategori kurang. Modus muncul pada nilai 80 , sebanyak 4 siswa (36\%) Nilai rata-rata kelas adalah 73 . Refleksi yang dilaksanakan pada pra siklus menghasilkan beberapa masukan, yakni perlu adanya tambahan sumber belajar bagi siswa, siswa kurang serius dalam melaksanakan pembelajaran, lebih mengarah pada kegiatan bermain semata-mata. Sehubungan dengan hal tersebut, maka penelitian ini masih akan dilanjutkan pada siklus II.

Hasil penerapan metode pada siklus II dilaksanakan pembelajaran dengan model pembelajaran Talking Stick yang telah direfleksi pada siklus I, KKM pada siklus II adalah 70, didapatkan data siswa tuntas pada tahap siklus II mencapai 10 siswa ( 91\%). Analisis berdasarkan kategori dikatakan siswa dalam kategori istimewa sebanyak 3 siswa (27\%). Siswa dalam kategori sangat baik sebanyak 3 siswa (27\%), siswa dalam kategori baik sebanyak 5 siswa (46\%). Modus muncul pada nilai 80 , sebanyak 5 siswa (46\%). NIlai rata-rata kelas adalah 85 . Refleksi yang dilaksanakan pada siklus II pertemuan 2 adalah siswa dapat meningkatkan prestasi belajarnya dengan sangat signifikan, dan pembelajaran berlangsung dengan lancar, karena bak siswa maupun guru dapat melaksanakan model pembelajaran Talking Stick dengan baik. Sesuai dengan hasil penelitian tersebut maka penelitian ini tidak akan dilanjutkan pada siklus berikutnya.

\section{PEMBAHASAN}

Perbandingan hasil belajar siswa pada siklus I dan siklus peningkatan prestasi belajar siswa pada siklus I Siswa tuntas sejumlah 8 siswa (73\%), sedangkan pada siklus II sejumlah 11 siswa (100\%). Dengan demikian ada kenaikan sebesar $27 \%$ atau sebanyak 3 siswa dari 11 siswa. Nilai rata-rata kelas pada siklus I sebesar 73 dan pada siklus II mencapai 85. Dengan demikian terjadi kenaikan sebesar 17 poin.

\section{KESIMPULAN}

Pada siklus I Siswa tuntas sejumlah 8 siswa (73\%), sedangkan pada siklus II sejumlah 11 siswa (100\%). Dengan demikian ada kenaikan sebesar 27\% atau sebanyak 3 siswa dari 11 siswa. Nilai rata-rata kelas pada siklus I sebesar 73 dan pada siklus II mencapai 85. Dengan demikian terjadi kenaikan sebesar 17 poin. Berdasarkan hasil secara keseluruhan dari pelaksanaan Penelitian Tindakan Kelas ini, maka dapat diambil kesimpulan bahwa terjadi peningkatan prestasi belajar 
Vol. 2 No. 3, Juli 2018;

Pendidikan Agama Islam materi Rasul-Rasul Allah melalui model pembelajaran Talking Stick pada siswa kelas V di SDN 3 Gembleb Kecamatan Pogalan Kabupaten Trenggalek Semester II Tahun Pelajaran 2017/2018.

\section{SARAN}

Saran-saran sesuai dengan hasil penelitian kepada siswa disarankan untuk tetap aktif dalam belajar, bertanggung jawab, sehingga semua tugas dapat diselesaikan dengan baik dan tepat waktu. Selain itu juga disarankan agar benar-benar berupaya untuk lebih meningkatkan prestasi belajarnya sehingga siswa dapat mencapai keberhasilan yang optimal. Kepada guru, disarankan kepada guru untuk sedikit demi sedikit mengurangi kebiasaan mengajar yang sifatnya "teacher centered" sehingga siswa dapat berkembang maksimal. Selain itu pembelajaran akan menjadi lebih menarik dan bermakna. Kepada Sekolah, disarankan agar sekolah selalu memotivasi seluruh warga sekolah untuk bekerja dan menjalankan tugas sesuai dengan tugas pokok dan fingsinya masing-masing. Hal tersebut tentunya akan bermuara pada terciptanya sekolah yang lebih baik dan berkualitas serta dapat dipercaya oleh masyarakat.

\section{DAFTAR RUJUKAN}

Aqib, Zainal. 2012. Profesionalisme Guru dalam Pembelajaran. Surabaya: Insan Cendekia

Arikunto, Suharsimi. 2010. Prosedur Penelitian Suatu Pendekatan Praktek. Jakarta: Rineka Cipta

Arikunto, Suharsimi. 2013. Prosedur Penelitian Suatu Pendekatan Praktek. Jakarta: Rineka Cipta

Arikunto, Suharsimi. 2011. Penelitian Tindakan Kelas. Jakarta. BumiAksara

Asrori, Mohamad. 2011 Psikologi Pembelajaran.Bandung; Wacana Prima

Djamarah, Syaiful Bahri.2011. Psikologi Belajar: Jakarta: Rineka Cipta

Fajri, Em Zul. 2008. Kamus Lengkap Bahasa Indonesia. Diffa Publisher

Fathurrohman, Muhammad.2012. Belajar dan Pembelajaran. Yogyakarta: Teras

Hajar, Ibnu. 2008. Penelitian Kuantitatif. Jakarta: Rineka Cipta

Hasibuan. 2000. Psikologi Belajar. Bandung: Remaja Rosda Karya

Imam, Khusnul. 2011. Belajar Mengamalkan Agama Islam. Pusat Kurikulum dan Perbukuan. Depdiknas.

Shoimin, Aris. 2014. 68 Model Pembelajaran Inovatif dalam Kurikulum 2013.Yogyakarta: Ar-Ruzz Media.

Surachmad Winarno. 2004. Pengantar Interaksi Belajar Mengajar. Bandung: Tarsito

Winataputra Udin S. 2003. Strategi Belajar Mengajar. Jakarta: Depdikbud.

......2006. Kurikulum Tingkat Satuan Pendidikan Sekolah Dasar. Jakarta: Dinas Pendidikan dan Kebudayaan. 